\title{
Development and Assessment of Black Seed Planter
}

\author{
Adel A. AL-Gezawe, Gamal A. El-Termezy and Ahmed I. Imam* (0)
}

Address:

Agricultural Engineering Research Institute Agricultural Research Center, Giza, Egypt.

*Corresponding author: Ahmed I. Imam, Email: a.emam@arc.sci.eg

Received: 02.07.2021; Accepted: 16.09.2021; Published: 17.09.2021

$\underline{10.21608 / \text { ejar.2021.78783.1114 }}$

\section{Abstract}

Black seed (Nigella sativa), which belongs to the botanical family of Ranunculaceae, is a widely used medicinal plant all over the world. Nigella sativa seeds and oil have been used in the treatment of different diseases. The aim of the present investigation is to develop and evaluate the performance of a planter to be used for planting black seed. The developed black seed planter consists of three hitching points, frame, seed hopper, four vertical rollers with cells metering, shovel furrow openers and chain covering devices. Laboratory experiments were carried out as a function of change in metering device speed; cells shape (cylinder and truncated cone) and cells volume $(0.98,1.41$ and $1.92 \mathrm{~cm} 3)$. While, field experiments were conducted to optimize machine forward speed. The machine performance was studied in terms of seed damage, plant scattering, emergency, crop yield, specific energy and planting cost. The experimental results reveal that the developed black seed planter is recommended to be used under the following conditions: forward speed of $3 \mathrm{~km} / \mathrm{h}$ and cell volume of 1.92 $\mathrm{cm} 3$ with truncated cone cells. The obtained results at optimum conditions were: plant emergence of $95.46 \%$, seed yield $0.773 \mathrm{Mg} / \mathrm{fed}$, ground wheel slip of $3.6 \%$, required power of $3.41 \mathrm{~kW}$, specific energy of $3.32 \mathrm{~kW} \mathrm{h/fed}$, field capacity of 1.03 $\mathrm{fed} / \mathrm{h}$, operational cost of $55.81 \mathrm{~L} . \mathrm{E} / \mathrm{fed}$, and production cost of $72.23 \mathrm{~L} . \mathrm{E} . / \mathrm{Mg}$.

Keywords: Black seed, Nigella sativa, planter and metering device.

\section{INTRODUCTION}

Medicinal and aromatic plants are a significant source of revenue for the country. They are economically valuable in both domestic and international markets. Egypt exported about 85 percent of dry herbs, seeds, fruits, and flowers, and about 98 percent of aromatic oils and masticates from the total production area, with the cultivated area reaching about 70000 feddans. Nigella sativa is one of the world's most valuable medicinal aromatic plants. Nigella sativa is primarily grown in Egypt, where the climate is dry and mild, and local farmers successfully grow it from seed in October and November (MALAR, 2007). Black seeds and oil have long been used to treat a variety of diseases all over the world. The seeds are usually eaten alone, in combination with honey, or in many food preparations. It is included in the list of natural drugs in various medicines, including Tibb-e-Nabavi (Prophet Mohammad's medicine). Cooking is done with the oil obtained by pressing the seeds. In the Bible, the black seed is referred to as the curative black seed and is referred to as the Melanthion of Hippocrates and Discroides, as well as the Gith of Pliny (Rajsekhar et al., 2011).

Black seed (Nigella sativa L.) is a Ranunculaceae family annual medicinal plant with black small seeds used as a seasoning and in herbal medicine. It can be found in the Mediterranean, Western Asia, and the Middle East. This plant was being used as a spice and food preservative in many countries for thousands of years, as well as a defensive and health remedy in traditional folk medicine for the treatment of a variety of disorders. It is taken into account in the pharmaceutical and food sectors. Antiviral, antibacterial, antipyretic, carminative, and blood sugar lowering properties are all found in seeds or their oil extracts (Darakhshan et al., 2015). Different types of seed drills and planters which could be used for planting different crops including black seeds were found in the literature review, for used field and laboratory experiments to assess the efficiency of a manually operated two-row okra planter. With $70 \mathrm{~cm}$ spacing and an average depth of $8 \mathrm{~mm}$ to $9 \mathrm{~mm}$, they were able to achieve a percentage difference of 4.97 percent between the weights of seeds discharged from the two hoppers at a seed rate of $0.36 \mathrm{~kg} / \mathrm{h}$ and a percentage damage of 3.51 percent. The planter's total average performance was 71.75 percent (Bamgboye and Mofolasayo, 2006). Created a seed drill system for planting soaked and hasted seed rice in rows. At a forward speed of $0.64 \mathrm{~m} / \mathrm{s}$, the results showed a decrease in weed plants per square meter and a 97 percent increase in germination percentage (Ibrahim et al., 2008). Made a new seed drill for planting black seed. The developed seed drill is tested using four forward speeds [3.13, 3.54, 4.28, and $4.85 \mathrm{~km} / \mathrm{h}$ ], four hill distances [zero (before development), 15, 30, and $45 \mathrm{~cm}$ (after development), and a constant distance between rows of $40 \mathrm{~cm}$. The optimum distance between hills was calculated to be $30 \mathrm{~cm}$ in order to achieve a higher seed yield of $815 \mathrm{~kg} / \mathrm{fed}$, lower energy of $7.24 \mathrm{~kW}$.fed/Mg, production cost of $26.44 \mathrm{L.E} / \mathrm{Mg}$, and higher germination ratio of 95.37 percent with higher field performance of 89.41 percent at a forward speed of $3.13 \mathrm{~km} / \mathrm{h}$. As a result, the findings suggested using a $30 \mathrm{~cm}$ gap between hills and a ranged forward speed of $3.13 \mathrm{~km} / \mathrm{h}$ (Afify, 2009). designed and built a manually operated flute planter/fertilizer distributor that was found to be $94 \%$ effective in seed spacing but couldn't be used on ridged seed beds and takes a long time to adjust seed drill size and seed spacing (Adisa and Braid ,2012). Designed and built a manually operated template row planter to improve planting efficiency and minimize drudgery. Seeds of various sizes can be planted at different depths and with different spacing between them. It also improved seed planting and seed/fertilizer placement accuracy, and it was made of a sturdy and low-cost material that small-scale peasant farmers could afford. The working, adapting, and retaining concepts were simplified to enable unskilled operators to handle them effectively (farmers) (Kyada and Patel, 2014). Workshops can easily make the manual seed Planter machine from local components. The only specialized items required are the seed meters plunger which can be sourced at 
an inexpensive price from a local promoter and the plunger is easily manufactured. By using this machine, the achievement of the flexibility of distance and depth variation for different seed plantations is possible (Kyada and Patel, 2014). Crafted and tested a metering unit planter for cowpea, maize, and soybean planting. The planter had a field productivity and field ability of 76.3 percent and $0.39 \mathrm{ha} / \mathrm{h}$, respectively, for cowpea, maize, and soybean, with seed rates of $0.25 \mathrm{~kg} / \mathrm{ha}, 0.18 \mathrm{~kg} / \mathrm{ha}$, and $0.21 \mathrm{~kg} / \mathrm{ha}$. An average spacing of $40.8 \mathrm{~cm}$ and depth of $3.98 \mathrm{~cm}$ resulted in a 3.54 percent, 2.32 percent, and 1.32 percent difference in seed damage of cowpea, maize, and soybean, respectively (Adekanye, 2015).

Evaluated three seed-metering mechanisms, viz. slanting, semicircular and rectangular shape for three paddy varieties and investigated the influence of the selected levels of variables, viz. forward speed, cell shape and inclination of seed metering plate on performance parameters of seed metering. Mean seed spacing, miss index and seed damage were found to increase with increase in forward speed and angle of inclination while multiple index decreased with increase in forward speed and angle of inclination for all metering plates tested. The mean seed spacing of $14.8 \mathrm{~cm}$ close to theoretical seed spacing of $15 \mathrm{~cm}$, highest quality feed index of $88.1 \%$, lowest miss index of $6.1 \%$ and minimum seed damage of $0.38 \%$ were observed in slanting type metering plate at an angle of $35^{\circ}$ and at a forward speed of $2 \mathrm{~km} / \mathrm{h}$. Hence, for design of precision paddy planter, the optimum parameters, like slanting type metering plate with angle of inclination 350 and forward speed of $2 \mathrm{~km} / \mathrm{h}$ can be used to achieve best results (Prajaiah, et al., 2016). A push carrot seed seeder was developed and tested. The newly developed carrot seeder's output was best at a forward speed of $1.0 \mathrm{~m} / \mathrm{s}$, with a falling efficiency of 96.7 percent, a coefficient of variance of 1.7 percent, a field efficiency of 88.2 percent, germination of 82.3 percent, and an average number of seeds deposited of 2.5. It was also discovered that the unit was 76 percent faster than the standard method of planting carrot seeds (Valentin, 2016).

The main objective of the present investigation work was to use modified planter for planting black seed. The following criteria were taken into consideration:1) Develop a planter to be suitable for black seed planting. 2) Optimize some different operating parameters affecting the performance of the developed planter.

\section{MATERIALS AND METHODS}

The main experiments were carried out at a private farm, Zagazig City, Sharkia Governorate. The developed black seed planter was constructed at a local workshop. Fig. 1 showed the developed black seed planting machine.

Materials:

The developed black seed planter:

It consists of the main frame with three hitching points, seed box, composting box, four vertical rollers with four round cells metering device, four plastic seed tubes, four shovel furrow openers, four chain covering devices and four diggers.

The main frame: The frame was built from iron angle with dimensions of $50 \times 50 \times 5 \mathrm{~mm}$. The frame has length of $200 \mathrm{~cm}$, width of $60 \mathrm{~cm}$ and height of $65 \mathrm{~cm}$.

Box: A box was divided into two parts: the first part is seed box while the second part is fertilizer box for adding chemical fertilizer (NPK) during planting. All parts in box were built from galvanized steel sheet of $3 \mathrm{~mm}$ thick, with dimensions of 170 $\times 50 \times 45 \mathrm{~cm}$ and $60^{\circ}$ sloping bottom.

Metering device: The metering device consists of vertical roller with four round cells, gate, a cleaning brush, housing and cover. The plastic vertical roller has a diameter of $96 \mathrm{~mm}$ and width of $30 \mathrm{~mm}$. It has four round cells with different shapes and different diameters. Fig. 2 shows colored isometric of the metering device.
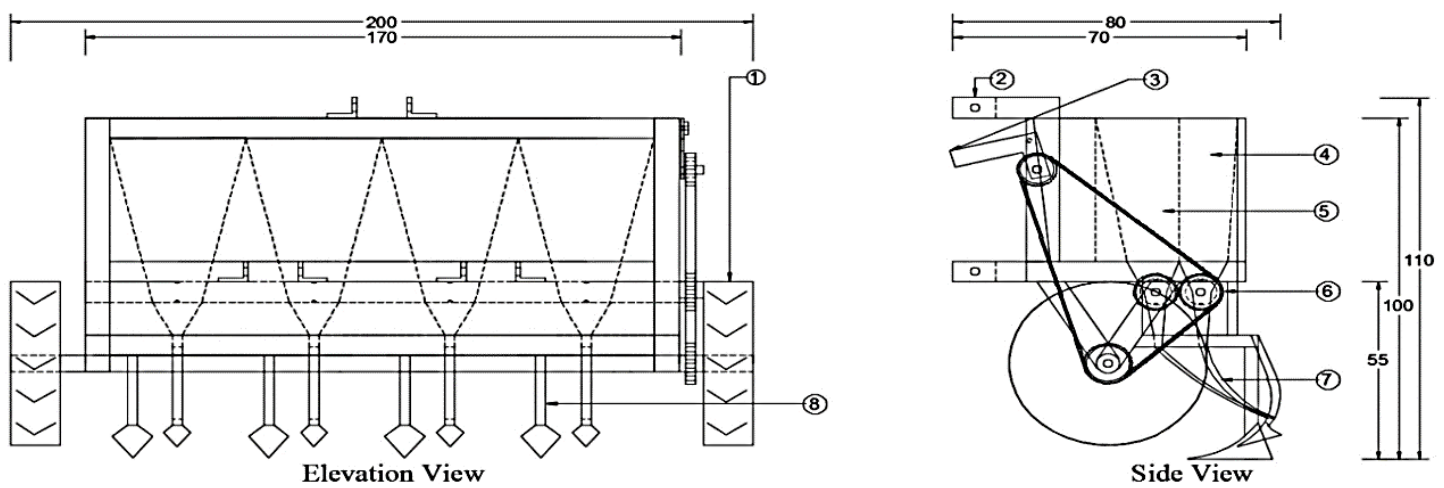

\begin{tabular}{|l|l|l|l|l|l|l|l|}
\hline No. & Part name & No. & Part name & No. & Part name & No. & Part name \\
\hline 1 & wheels & 3 & Tensioner gear & 5 & fertilizer box & 7 & Seed tube \\
\hline 2 & Hitching points & 4 & Seed box & 6 & Metering device & 8 & Furrow opener \\
\hline
\end{tabular}

Fig.1. Schematic views of the developed black seed planter 


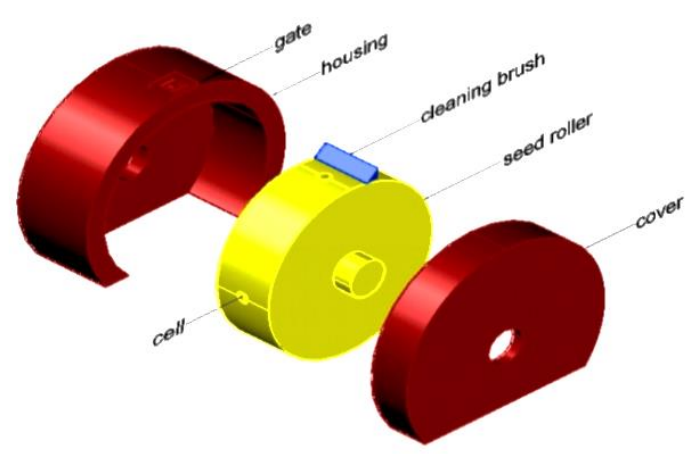

Fig.2. colored isometric of the metering device

A cleaning brush: A cleaning brush was attached at top of the seed roller to wipe any extra seed in cells. It was made of rubber with $5 \mathrm{~mm}$ thickness and $30 \mathrm{~mm}$ width. It is under a square gate with dimensions of $15 \times 15 \mathrm{~mm}$.

Seed tube: Seed tubes were made from plastic with diameter of $5 \mathrm{~cm}$, length of $60 \mathrm{~cm}$ and thickness of $2 \mathrm{~mm}$.

Furrow opener: It was a share with width of $30 \mathrm{~cm}$.

Covering device: It consists of four iron rings with diameter of $10 \mathrm{~cm}$.

Overall dimensions: The overall dimensions of the developed black seed planter are $200 \mathrm{~cm}$ in length, $80 \mathrm{~cm}$ in width and $110 \mathrm{~cm}$ in height and its mass is about $350 \mathrm{~kg}$.

Tractor: A Kubota tractor (Model: L295) of $30 \mathrm{hp} \mathrm{(22.4} \mathrm{kW)} \mathrm{was} \mathrm{used} \mathrm{as} \mathrm{a} \mathrm{power} \mathrm{source} \mathrm{for} \mathrm{operating} \mathrm{the} \mathrm{developed} \mathrm{machine.}$ Black seeds: Physical and mechanical properties of black seeds are shown in Table 1. (Al-Mahasneh, et al. 2008), and Fig.3 showed the view of black seed plants.

Table 1: Physical dimensions and mechanical properties of black seeds

\begin{tabular}{|l|l|l|l|}
\hline Property & Range of values & Mean value & Standard deviation \\
\hline Moisture content (\% w.b.) & $5.25-5.35$ & 5.29 & 0.051 \\
\hline Length (mm) & $2.85-3.27$ & 3.19 & 0.207 \\
\hline Width (mm) & $1.36-1.81$ & 1.58 & 0.143 \\
\hline Thickness (mm) & $0.84-1.22$ & 1.03 & 0.12 \\
\hline Geometric mean diameter (mm) & $1.55-1.88$ & 1.73 & 0.09 \\
\hline Effective diameter (mm) & $1.63-1.77$ & 1.69 & 0.05 \\
\hline Sphericity (\%) & $51.6-60.7$ & 55.90 & 2.6 \\
\hline Roundness (\%) & $66.0-71.4$ & 68.10 & 2.1 \\
\hline Thousand seeds mass (g) & $2.35-2.85$ & 2.57 & 0.16 \\
\hline True density (kg m $\left.{ }^{-3}\right)$ & $992.0-1094.1$ & 1028.90 & 38.5 \\
\hline Bulk density $\left(\mathrm{kg} \mathrm{m}^{-3}\right)$ & $538.4-568.4$ & 550.40 & 11.2 \\
\hline Porosity $\%)$ & $44.6-48.1$ & 46.50 & 1.3 \\
\hline
\end{tabular}

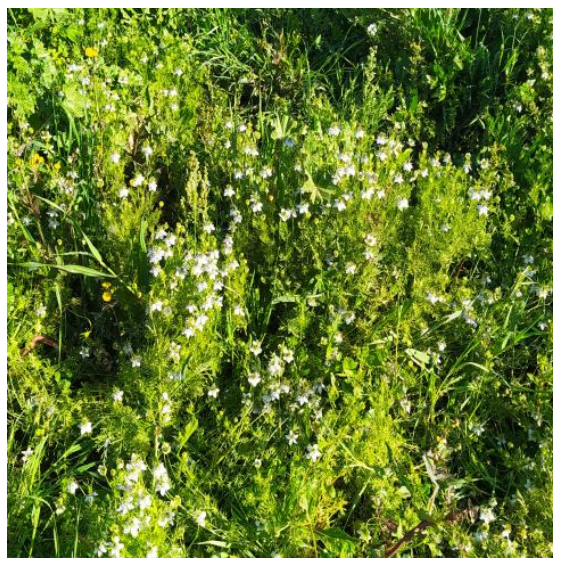

(a)

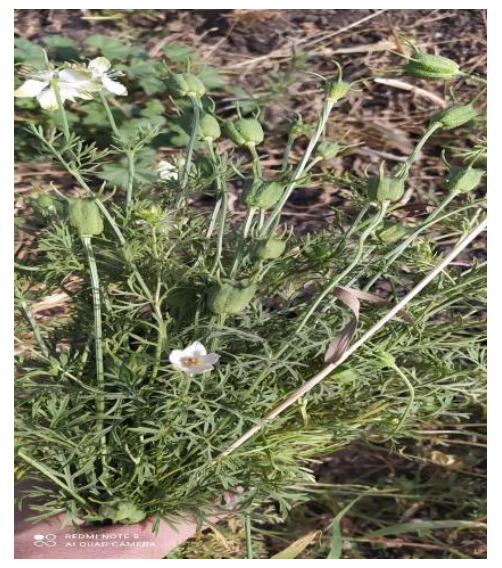

(b)

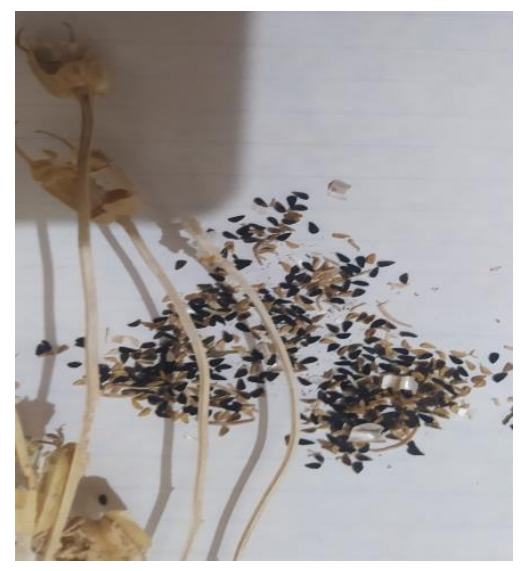

(c)

Fig.3. views of black seed plants. . (a) Plants. (b) Capsules. (c) Seeds

\section{Methods:}

Two experimental groups were carried out to study the effect of some operating-factors affecting the developed black seed planter performance as follows: 
(1) Laboratory experiments were carried out to find the optimum factors affecting feed rate, grain damage and germination. These factors are: metering device speed, cell shape (cylinder and truncated cone) and cell volumes. Fig.4 shows colored isometric for shapes of cells with different volume. All treatments were replicated three times to give more reliable averages.

(2) Field experiments: were carried out in the field under four forward speeds of 2,3, 4, and $5 \mathrm{~km} / \mathrm{h}$ to determine the following indicators: emergence percentage, longitudinal seed distribution, slip of ground wheel, draft force, power, specific energy, field capacity, crop yield, and estimating the costs of using the developed planting machine.

Planting intensity ranges were $2-3 \mathrm{~kg} / \mathrm{fed}, 30 \mathrm{~cm}$ longitudinal distances between hills and $40 \mathrm{~cm}$ between rows (according to recommendation of (Medicinal and Aromatic Plants department, Horticulture Research Institute, Ministry of Agriculture, 2005)). The planting intensity was varied according to number of seed per cell and forward speed.

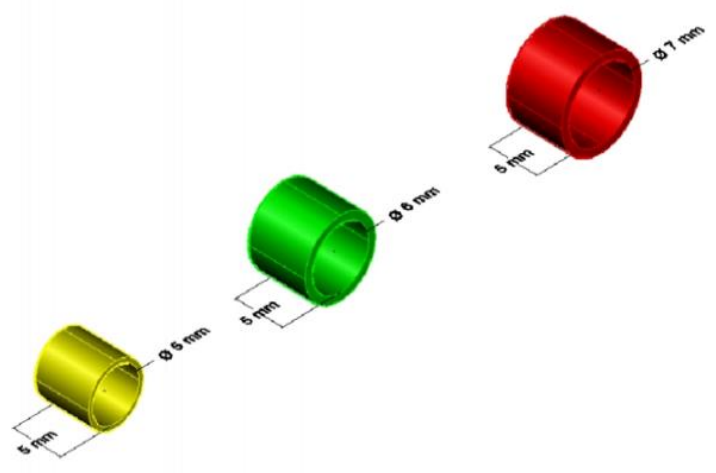

(a)

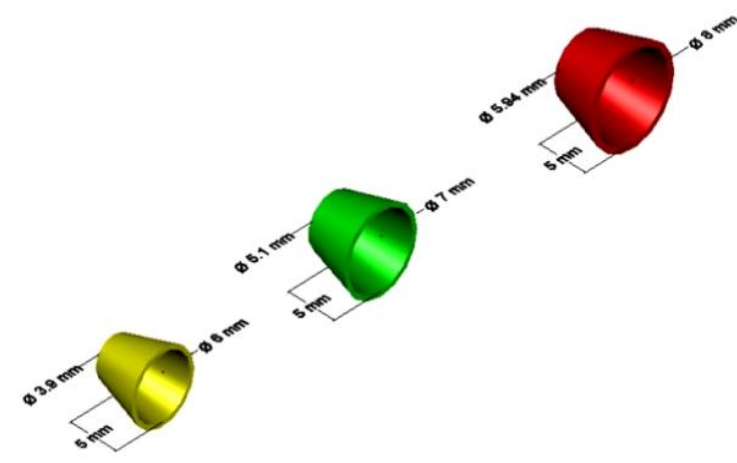

(b)

Fig.4. colored isometric for shapes of cells with different volumes. (a) Cylinder shape. (b) Truncated cone shape

\section{Tested parameters:}

Metering device speed: five metering device speeds of $20,30,40,50,60$ and $70 \mathrm{rpm}(0.1,0.15,0.2,0.25,0.3$ and $0.35 \mathrm{~m} / \mathrm{s})$ or ground speeds of $20,30,40,50$ and $60 \mathrm{rpm}(0.4,0.6,0.8,1.0,1.2$ and $1.4 \mathrm{~m} / \mathrm{s})$ were tested in laboratory.

Cell shape: two cell shapes of cylinder and truncated cone were tested in laboratory and field.

Cell volume: Three cell volumes of $0.98,1.41$ and $1.92 \mathrm{~cm}^{3}$ were tested in laboratory and field.

Forward speed: Four forward speeds of 2, 3, 4 and $5 \mathrm{~km} / \mathrm{h}$ were tested in the field.

\section{Measurements:}

- Seed discharge: Seed discharge was measured in laboratory and field tests at different ground wheel speeds of 20,30,40, 50,60 and $70 \mathrm{rpm}$ or metering device speeds of $20,30,40,50,60$ and $70 \mathrm{rpm}$ cell shape (cylinder and truncated cone) , cell volumes $\mathrm{cm} 3$ and forward speeds of 2, 3, 4 and $5 \mathrm{~km} / \mathrm{h}$. seeds were mixed with sand with ratio of 1 seed: 2 sand. The discharge seeds were collected in plastic bags during a certain number of ground wheel revolutions.

- Seed damage and germination: In the previously mentioned factors, the damaged seeds were counted manually and weighed. The percentage of seed damage were calculated, and related to the seed discharge. One thousand black seeds were germinated laboratory to give the germination ratio before passing through the metering device.

The actual germination ratio of seeds after passing through the metering device was calculated by the following equations (Yehia, 1997):

Actual germination percent $=$ Germination $\%$ of unused seeds $-($ Visible seed-damage, $\%+$ invisible seed damage, \%)

$$
\text { Visible seed-damage, } \%=
$$$$
\frac{\text { Mass of damaged seed }}{\text { Total weight of seed }}
$$$$
\times 100
$$

Invisible seed damage, $\%=$ (No. of shoots / Total No. of seeds) $\times 100$

- Emergence percentage: The number of plants per meter of the row was counted for the four tested forward speeds of 2,3, 4 , and $5 \mathrm{~km} / \mathrm{h}$ and the three cell volumes of $0.98,1.41$ and $1.92 \mathrm{~cm}^{3}$ for cell shape (cylinder and truncated cone) to determine the emergence percentage according to the following formula:

$$
\text { Emergence percentage }=\frac{\text { Germinated seeds }}{\text { Total seeds }} \times 100
$$

- Plant scattering: For forward speeds, the black seed plants were counted to determine the longitudinal plant distribution at different previously mentioned-factors.

The plant distribution was analyzed to determine coefficient of variation (CV) of seeds spacing according to the following formula:

$$
\mathrm{CV}, \%=\frac{\mathrm{SD} \text { of plant spacing }}{\text { Recommended plant spacing }} \times 100
$$

Where: SD is the standard deviation.

$\mathrm{SD}=\mathrm{V}$ (Plant spacing - Recommended plant spacing $)^{2}$ 
The coefficient of variation less than $10 \%$ is considered excellent and with value less than $20 \%$ is considered acceptable for most field applications as stated by (Coates, 1992).

- Missing hill percentage: The missing hill percentage was calculated according to the following formula (Grewal, 2014):

$$
\text { Missing hills, } \%=\frac{\text { Number of missing plants per } \mathrm{m}^{2}}{\text { Total plants per } \mathrm{m}^{2}} \times 100
$$

- Slip of ground wheel: is an important factor that affects sowing rate per area. The percentages of slip were estimated for four forward speeds. Slippage percentage was calculated by using the following equation (Awady, 1992).

$$
\text { Slippage, } \%=\frac{\text { Actual distance }- \text { Theoretical distance spacing }}{\text { Theoretical distance }} \times 100
$$

Where: theoretical dist. $=$ No. of wheel revs. $\mathrm{x} \pi \mathrm{x}$ wheel diam.

- Total and black seed yield: The total and yield of each plot was measured to study the effect of the above mentioned factors on black seed crop. A frame of $1 \times 1 \mathrm{~m}^{2}$ was used for measuring the yield. The yield of the crop located within the frame was measured. The average total yield was calculated for all treatments in $\mathrm{Mg} / \mathrm{fed}$ (ton/fed).

- Theoretical field capacity: It was determined using the following equation:

$$
\text { F.C.th, fed/h = S x W / } 4200
$$

Where: F.C.th: Theoretical productivity of the machine, fed/h., S: machine forward speed, $\mathrm{m} / \mathrm{h}$. and W: machine width, $\mathrm{m}$.

-Actual field capacity: It was calculated using the following equation:

$$
\text { F.C. act, } \mathrm{fed} / \mathrm{h}=60 / \mathrm{Tu}+\mathrm{Ti}
$$

Where: F.C. act: The actual capacity of the machine, fed/h, Tu: the utilized time per fed, min. and Ti: the summation of time lost per fed, min.

-Field efficiency: It was calculated using the following equation:

$\eta f, \%=$ F.C. act $/$ F.C.th $\times 100$

Where: $\eta f=$ Filed efficiency, \%, F.C.act. = Actual field capacity, fed $/ \mathrm{h}$ and F.C.th. $=$ Theoretical field capacity, fed. $/ \mathrm{h}$.

- Fuel consumption: Fuel consumption per unit time was determined using a calibrated tank (refilling method) to measure the volume of fuel consumed during the operation time.

- Required power: The following formula was used to estimate the required power (Donnell, 1983):

$\mathrm{RP}=1 / 75 \times 1 / 1.36 \times 1 / 3600 \times 427 \times \mathrm{fC} \times \mathrm{PE} \times \mathrm{LCV} \times \eta_{\text {thb }} \times \eta_{\mathrm{m}}$

For diesel engine, the consumed power can be calculated as:

$$
\mathrm{RP}=\quad 3.16 \times 427 \times \mathrm{fc}
$$

Where: $\mathrm{RP}$ is the required power, $\mathrm{kW}, \mathrm{fc}$ is the fuel consumption, $\mathrm{l} / \mathrm{h}, \mathrm{PE}$ is the density of fuel, $\mathrm{kg} / \mathrm{L}$ (the density of Diesel = $0.85 \mathrm{~kg} / \mathrm{L}), \mathrm{LCV}$ is the lower calorific value of fuel, $(11000 \mathrm{kcal} / \mathrm{kg}), \eta$ thb is the engine thermal efficiency ( $35 \%$ for Diesel), 427 is the thermo-mechanical equivalent, $\mathrm{kg} \cdot \mathrm{m} / \mathrm{kcal}$, and $\eta \mathrm{m}$ is the mechanical efficiency of the engine ( $80 \%$ for Diesel).

- Specific energy: it can be calculated by using the following equation:

$$
\text { Specific energy, } \mathrm{kW} . \mathrm{h} / \mathrm{fed} .=\frac{\text { Power required, } \mathrm{kW}}{\text { Actual field capacity, fed } / \mathrm{h}} \times 100
$$

- Estimation cost: The hourly cost was calculated according to equation of (Awady, 1978) in the following form:

Where:

$$
C=P / h[1 / a+i / 2+t+r]+(1.2 \times w \times f \times s)+m / 144
$$

$$
\begin{array}{ll}
\mathrm{C}=\text { Hourly cost, L.E/h. } & \mathrm{P}=\text { Price of machine, } \mathrm{L} . \mathrm{E} . \\
\mathrm{h}=\text { Yearly working hours, } \mathrm{h} / \text { year. } & \mathrm{a}=\text { Life expectancy of the machine, year. } \\
\mathrm{i}=\text { Interest rate/year. } & \mathrm{F}=\text { Fuel price, } \mathrm{L} . \mathrm{E} / \mathrm{l} . \\
\mathrm{t}=\text { Taxes, over heads ratio. } & \mathrm{r}=\text { Repairs and maintenance ratio. } \\
\mathrm{m}=\text { Monthly average wage, L.E } & 1.2=\text { Factor accounting for lubrications. } \\
\mathrm{W}=\text { Engine power, hp. } & \mathrm{S}=\text { Specific fuel consumption, } \mathrm{l} / \mathrm{hp} . \mathrm{h} . \\
144=\text { Reasonable estimation of monthly working hours. }
\end{array}
$$

Operational cost can be determined using the following equation:

Operational cost, L.E./fed =

Hourly cost, L.E./h

Actual field capacity, fed/h

Cost per unit of production can be determined using the following equation:

$$
\text { Cost per unit of production, L.E. } / \mathrm{Mg}=\frac{\text { Operational cost, L.E./fed }}{\text { Crop yield, } \mathrm{Mg} / \mathrm{fed}}
$$

\section{RESULTS AND DISCUSSION}




\section{Results of laboratorial experiments}

Laboratory experiments were carried out to study the effect of metering device speed and cells shape on the performance of the developed metering device for three volumes cells.

\subsection{Effect of some different metering device parameters on seed discharge}

Fig. 5 shows the effect of metering device speed, cells shapes and cells volumes on seed discharge. Results showed that seed discharge increased by decreasing metering device speed, increasing cell volume and using truncated cone cells.

The maximum seed discharges of $1.51 \mathrm{and} 1.71 \mathrm{~kg} / \mathrm{fed}$ were obtained at metering speed of $20 \mathrm{rpm}$ and cell volume of 1.92 $\mathrm{cm}^{3}$ for cylinder and truncated cone cells respectively. Meanwhile, the minimum seed discharges of 0.479 and $0.569 \mathrm{~kg} / \mathrm{fed}$ were obtained at metering speed of $70 \mathrm{rpm}$ and cell volume of $0.98 \mathrm{~cm}^{3}$ for cylinder and truncated cone cells respectively. The decreasing of seeds discharge by increasing metering device speed It Is may be due to increasing the metering device acceleration than gravitation. While increasing seeds discharge by using truncated cone cells may be due to increasing the faced area of metering device cell under the seed box opening gate.
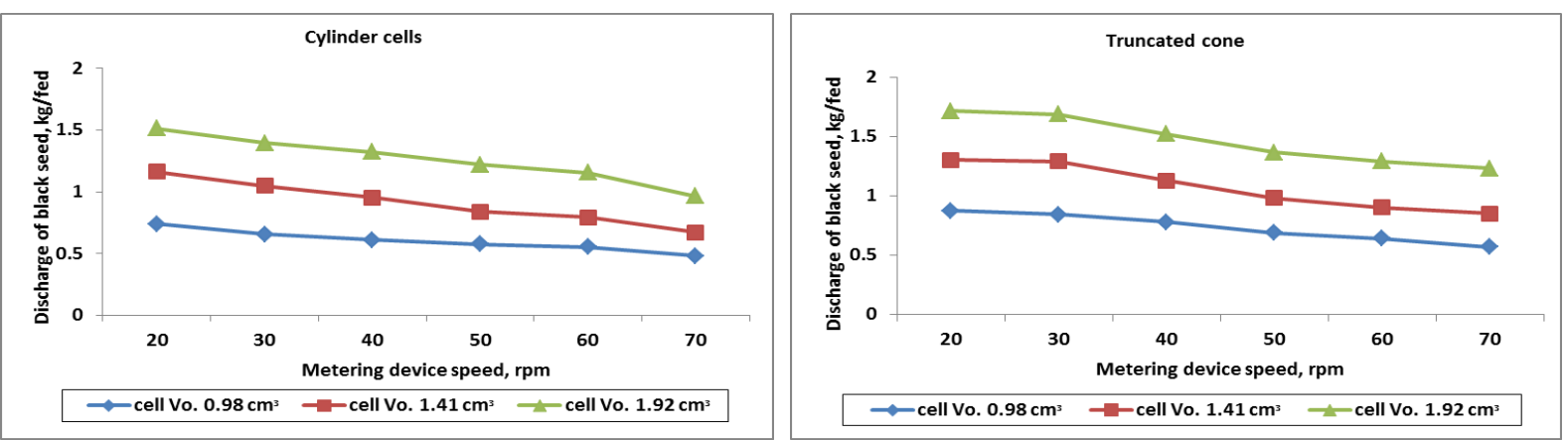

Fig.5. Effect of metering device speed, cells volume and cells shape on seed discharge

\subsection{Effect of some different metering device parameters on damage percent}

Fig. 6 illustrates the seed damage percentage using different values of metering device speed and cells volumes at different cells shapes. The obtained results indicate that, seed damage percentage increased by increasing metering device speed, decreasing cell volume and using cylinder cells.

The maximum seed damages of 2.48 and $2.05 \%$ were obtained at metering device speed of $70 \mathrm{rpm}$ and cell volume of 0.98 $\mathrm{cm} 3$ for cylinder and truncated cone cells respectively. Meanwhile, the minimum seed damages of 0.85 and $0.59 \%$ were obtained at metering device speed of $20 \mathrm{rpm}$ and cell volume of $1.92 \mathrm{~cm} 3$ for cylinder and truncated cone cells respectively. The increase in grain damage by increasing metering device speed is due to increasing momentum of grains (momentum = mass $x$ velocity) and increasing impact force accordingly.
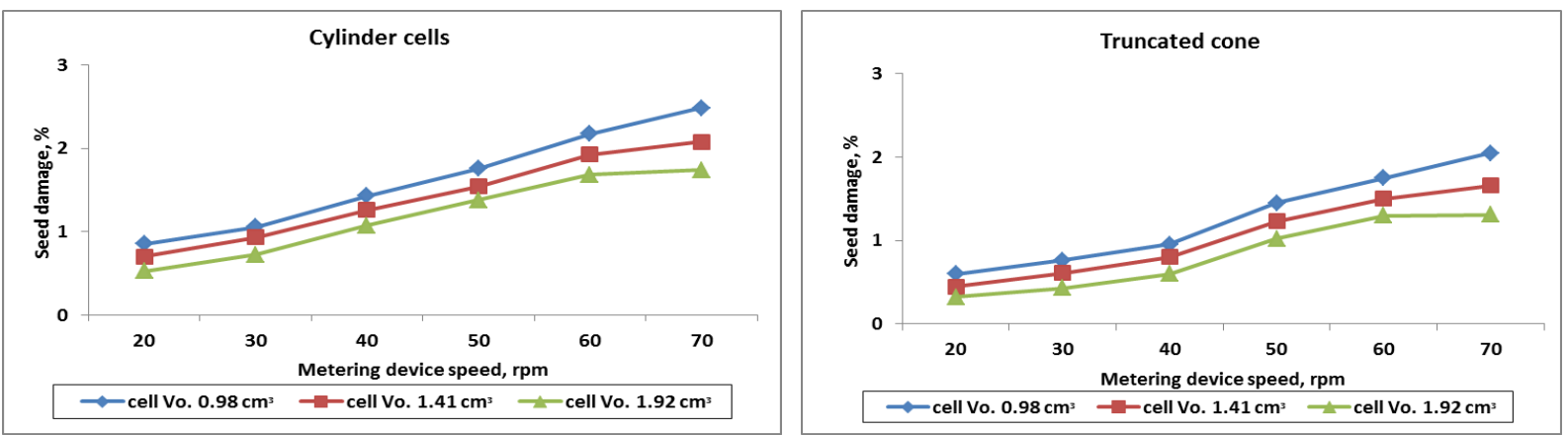

Fig.6. Effect of metering device speed, cells volume and cells shape on seed damages

\subsection{Effect of some different metering device parameters on germination percent}

Fig. 7 shows the effect of metering device speed, cells shapes and cells volumes on germination percent. Results showed that seed germination decreased by increasing metering device speed, decreasing cell volume and using cylinder cells.

The maximum seed germinations of 97.47 and $97.68 \%$ were obtained at metering device speed of $20 \mathrm{rpm}$ and cell volume of $1.92 \mathrm{~cm}^{3}$ for cylinder and truncated cone cells respectively. Meanwhile, the minimum seed germinations of 95.51 and 95.95 $\%$ were obtained at metering device speed of $70 \mathrm{rpm}$ and cell volume of $0.98 \mathrm{~cm}^{3}$ for cylinder and truncated cone cells respectively. 

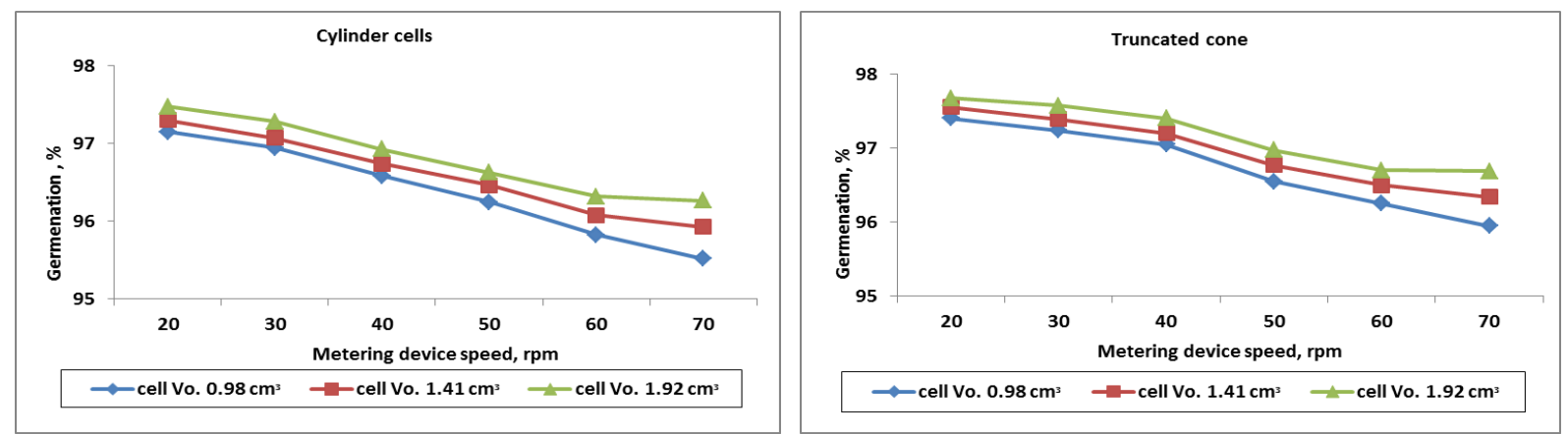

Fig.7. Effect of metering device speed, cells volume and cells shape on germination percent

\section{Results of field experiments}

\subsection{Effect of forward speed, cells shapes and cells volumes on seed discharge}

Fig. 8 shows the effect of forward speed, cells shapes and cells volumes on seed discharge. Results showed that seed discharge increased by decreasing forward speed, increasing cell size and using truncated cone cells.

The maximum seed discharges of 1.58 and $1.78 \mathrm{~kg} / \mathrm{fed}$ were obtained at forward speed of $2 \mathrm{~km} / \mathrm{h}$ and cell volume of 1.92 $\mathrm{cm} 3$ for cylinder and truncated cone cells respectively. Meanwhile, the minimum seed discharges of 0.419 and $0.509 \mathrm{~kg} / \mathrm{fed}$ were obtained at forward speed of $5 \mathrm{~km} / \mathrm{h}$ and cell volume of $0.98 \mathrm{~cm} 3$ for cylinder and truncated cone cells respectively. The decreasing of seed discharge of field experiments compared with laboratory experiments is due to ground wheel slip.
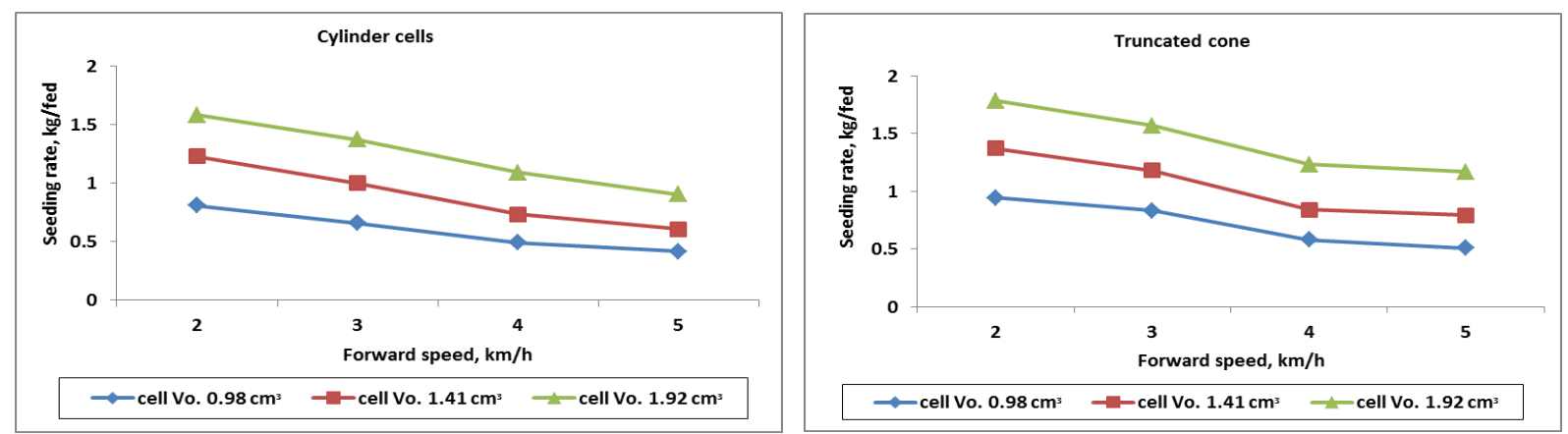

Fig.8. Effect of forward speed, cells volume and cells shape seed discharge

\subsection{Effect of forward speed, cells shapes and cells volumes on emergence percent}

Fig. 9 illustrates the emergence percentage of seed in the field using different values of forward speed and cells volumes at different cells shapes. Results showed that plant emergence decreased by increasing forward speed, decreasing cell size and using cylinder cone cells.

The maximum plant emergences of 95.52 and $95.93 \%$ were obtained at forward speed of $2 \mathrm{~km} / \mathrm{h}$ and cell volume of 1.92 $\mathrm{cm} 3$ for cylinder and truncated cone cells respectively. Meanwhile, the minimum plant emergences of 92.31 and $93.1 \%$ were obtained at forward speed of $5 \mathrm{~km} / \mathrm{h}$ and cell volume of $0.98 \mathrm{~cm} 3$ for cylinder and truncated cone cells respectively.

The decrease of plant emergence by increasing forward speed is due to the increase of metering device speed and the momentum of seeds which causes seed damage accordingly. Also, planting depth could not be thoroughly adjusted at high speed that tends to decrease plant emergence.
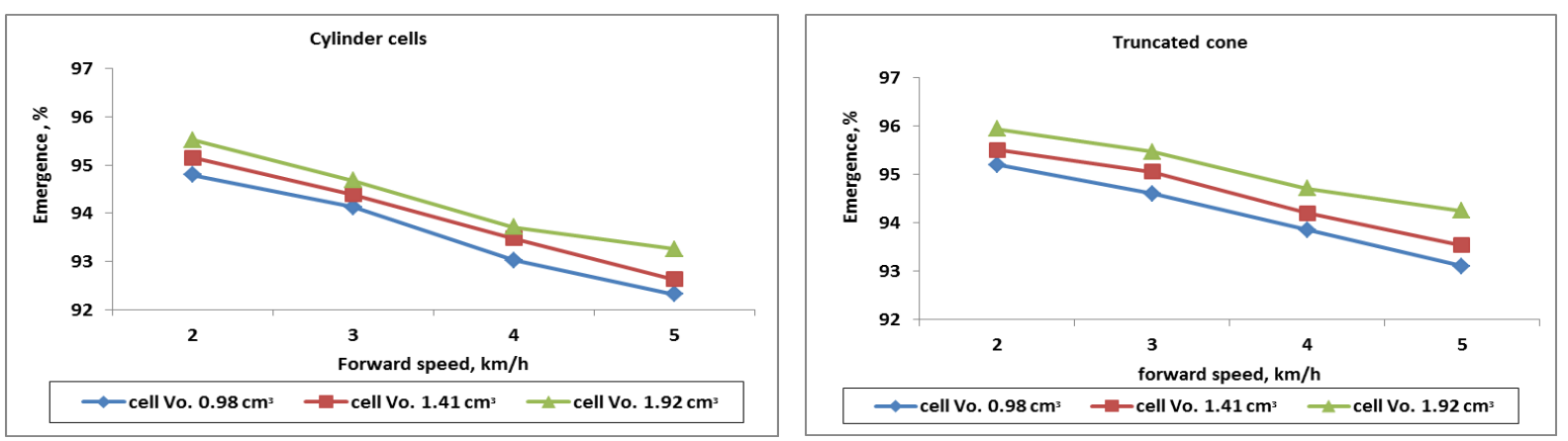

Fig.9. Effect of forward speed, cells volume and cells shape on emergence percent 


\subsection{Effect of forward speed, cells shapes and cells volumes on plant scattering}

The plants distribution was analyzed in order to determine the coefficient of variation (CV) of plant spacing. A low CV represents a row with more uniform seed spacing, while the vice versa was noticed with high values of CV. The plant scattering for different cutoff clearances and forward speeds were illustrated in Fig. 10.

The optimum conditions clarify that the forward speed of $2 \mathrm{~km} / \mathrm{h}$ and cell volume of $1.92 \mathrm{~cm} 3$ for truncated cone cells respectively had the best longitudinal distribution ( $C V$ of $3.22 \%$ ). The increase of plant scattering by increasing forward speed may be due to increasing the machine vibration and ground wheel slip. Meanwhile, the decrease of plant scattering by increasing cells volume may be due to decreasing the missing hills.
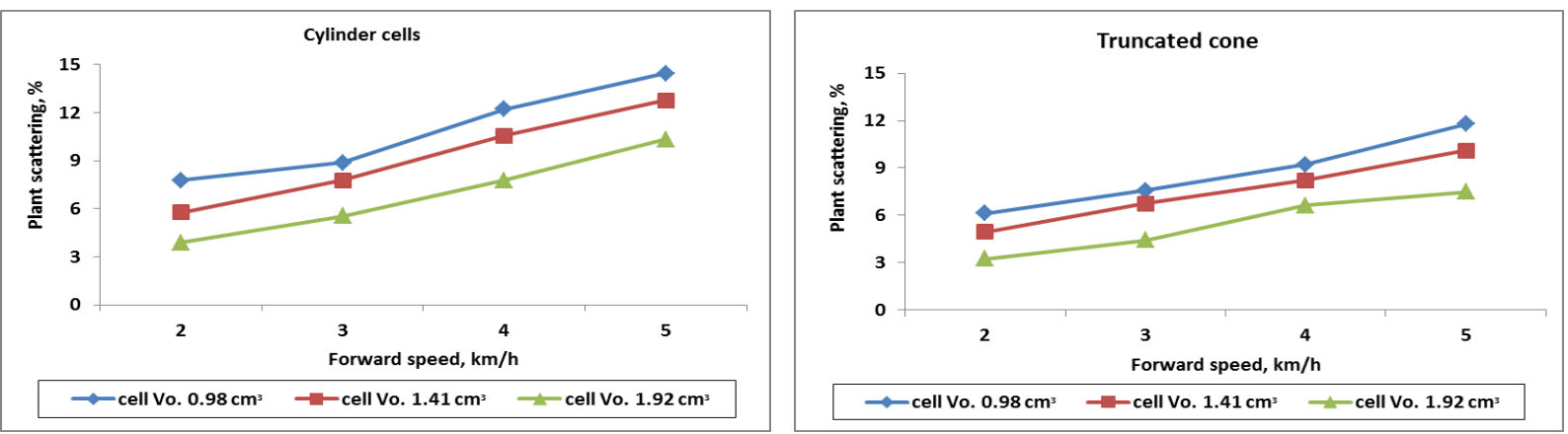

Fig.10. Effect of forward speed, cells volume and cells shape on plant scattering

\subsection{Effect of forward speed, cells shapes and cells volumes on missing hill percent}

Fig. 11 shows the effect of forward speed, cells shapes and cells volumes on missing hill percent. Missing hills increased with increasing forward speed, decreased cells volumes and using cylinder cone cells.

Results show that increasing forward speed from 2 to $5 \mathrm{~km} / \mathrm{h}$, increased missing hills from 0.77 to $3.53 \%$ and from 0.56 to $2.55 \%$ at $1.92 \mathrm{~cm} 3$ for cylinder and truncated cone cells respectively. The increase of missing hills by increasing forward speed may be due to increasing the machine vibration and ground wheel slip.
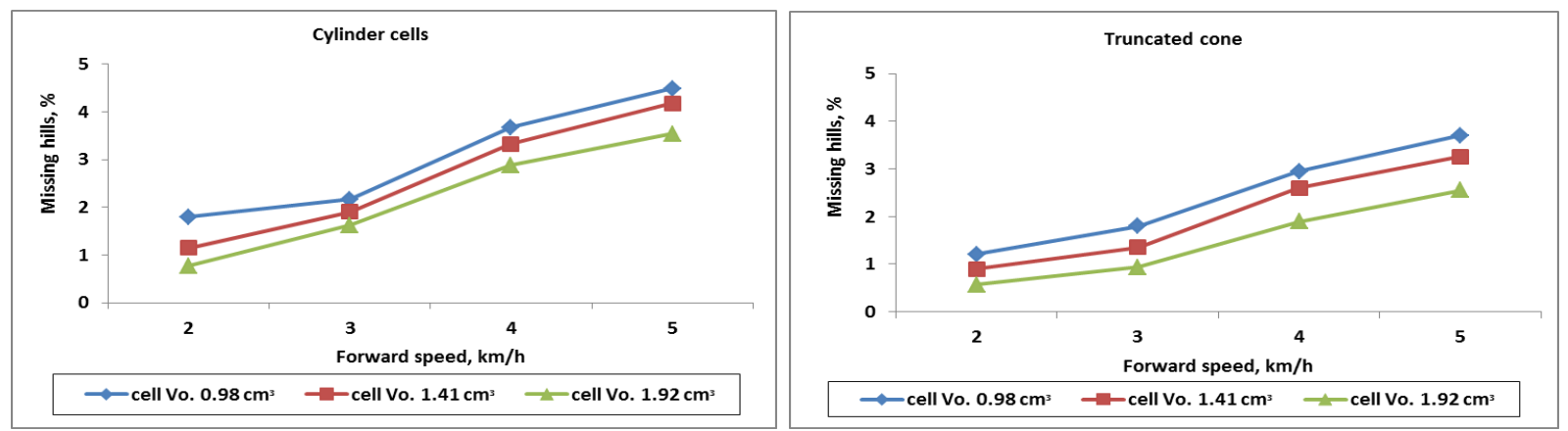

Fig.11. Effect of forward speed, cells volume and cells shape on missing hill percent

\subsection{Effect of forward speed, cells shapes and cells volumes on seed yield}

Fig. 12 shows the effect of forward speed, cells shapes and cells volumes on seed yield. Seed yield increased by decreasing forward speed, increasing cell size and using truncated cone cells.

The maximum seed yields of 0.76 and $0.79 \mathrm{Mg} / \mathrm{fed}$ were obtained at forward speed of $2 \mathrm{~km} / \mathrm{h}$ and cell volume of $1.92 \mathrm{~cm} 3$ for cylinder and truncated cone cells respectively. Meanwhile, the minimum seed yields of $0.61 \mathrm{and} 0.63 \mathrm{Mg} / \mathrm{fed}$ were obtained forward speed of $5 \mathrm{~km} / \mathrm{h}$ and cell volume of $0.98 \mathrm{~cm} 3$ for cylinder and truncated cone cells respectively. The decrease in seed yield by increasing forward speed is may be due to increasing the missing cells and the low plant emergence resulting from ground wheel slip at high speed. Also may be due to seed damage occurred by the effect of the metering device.

\subsection{Effect of forward speed on machine field capacity, efficiency and wheel slip}

Fig. 13 shows the effect of forward speed on actual field capacity, field efficiency and slip percent.

The maximum actual field capacity of $1.61 \mathrm{fed} / \mathrm{h}$ was obtained with forward speed of $5 \mathrm{~km} / \mathrm{h}$. Meanwhile, the minimum actual field capacity of $0.72 \mathrm{fed} / \mathrm{h}$ was obtained with forward speed of $2 \mathrm{~km} / \mathrm{h}$.

The maximum field efficiency of $89.70 \%$ was obtained with forward speed of $2 \mathrm{~km} / \mathrm{h}$. Meanwhile, the minimum field efficiency of $79.53 \%$ was obtained with forward speed of $5 \mathrm{~km} / \mathrm{h}$.

The slip percent of press wheel increased with increasing forward speed. The maximum slip of $5.4 \%$ was obtained with forward speed of $5 \mathrm{~km} / \mathrm{h}$. Meanwhile the minimum slip of $3.3 \%$ was obtained with forward speed of $2 \mathrm{~km} / \mathrm{h}$. 

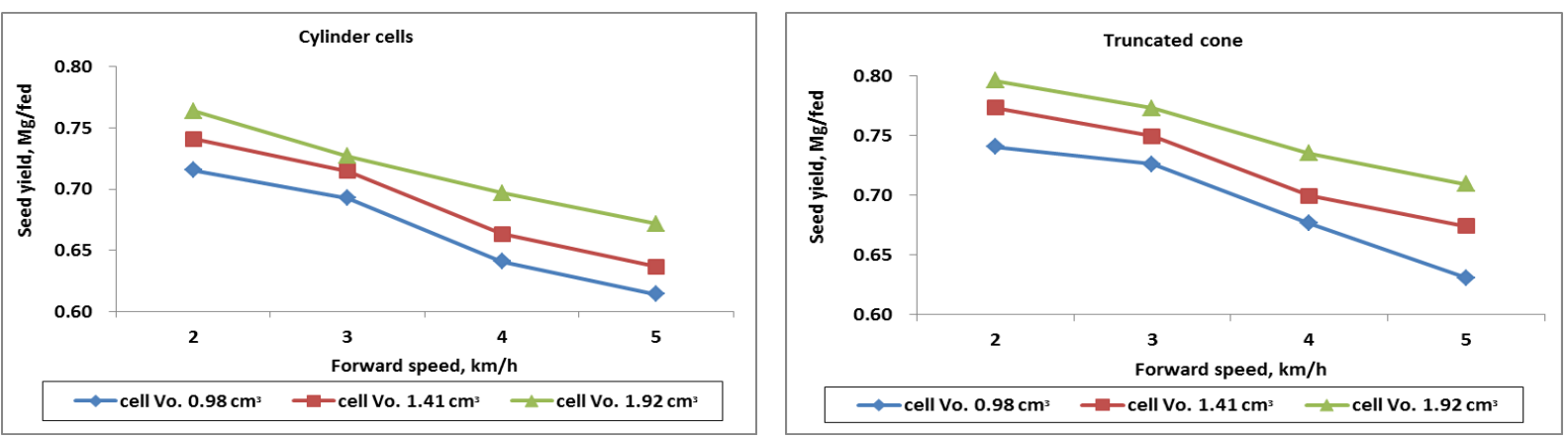

Fig.12. Effect of forward speed, cells volume and cells shape on seed yield
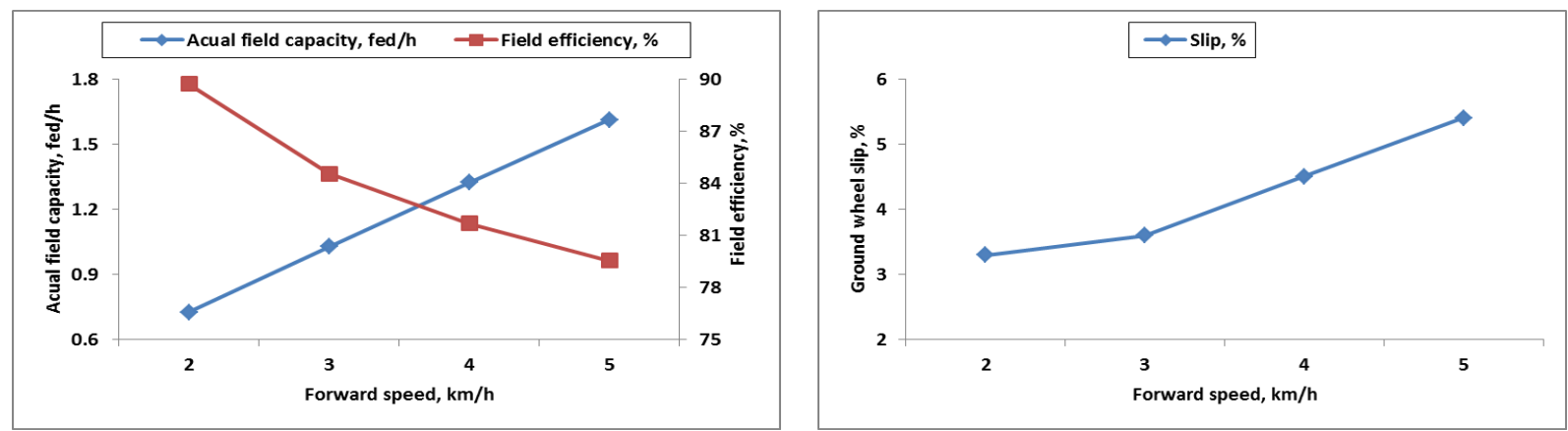

Fig.13. Effect of forward speed on actual field capacity, field efficiency and slip percent

\subsection{Effect of forward speed on fuel consumption, required power and specific energy}

Fig. 14 shows the effect of forward speed on required power and specific energy. The maximum required power and specific energy of $4.92 \mathrm{~kW}$ and $4.77 \mathrm{~kW} \mathrm{~h} /$ fed were obtained with forward speed of $5 \mathrm{~km} / \mathrm{h}$. Meanwhile the minimum values of 1.47 $\mathrm{kW}$ and $3.94 \mathrm{~kW} \mathrm{~h} /$ fed were obtained with forward speed of $2 \mathrm{~km} / \mathrm{h}$.

Increasing required power by increasing forward speed is may be due to the increased soil resistance that tends to increase the required power.

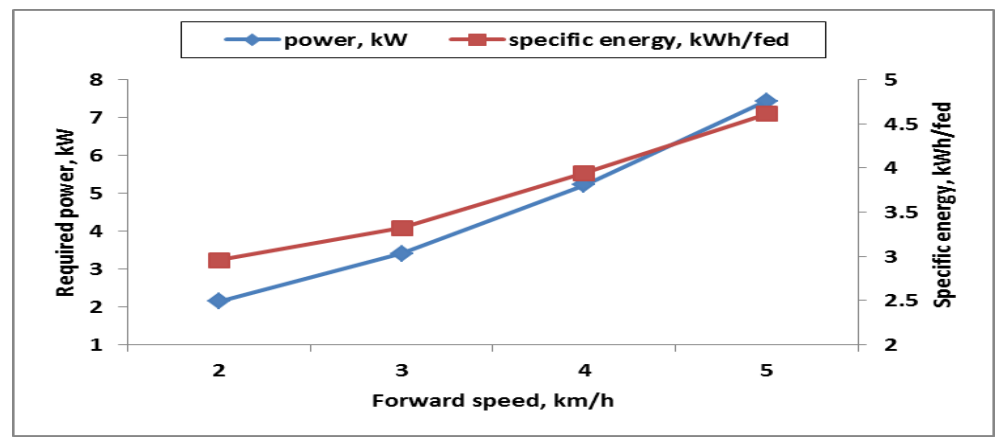

Fig.14. Effect of forward speed on required power and specific energy

\subsection{Operational and production costs of using the black seed planter}

Table 2 shows operational and production costs of using the developed black seed planter at different values of forward speeds, cells shapes and cells volumes.

The operational cost decreased by increasing forward speed. The minimum operational and production costs of 41.77 L.E./fed and 58.92 L.E./Mg were obtained using the developed black seed planter with forward speed of $5 \mathrm{~km} / \mathrm{h}$, cell volume of $1.92 \mathrm{~cm} 3$ for truncated cone cells. Meanwhile, The maximum operational and production costs of 74.60 L.E./fed and 104.23 L.E./Mg were obtained using the developed black seed planter with forward speed of $2 \mathrm{~km} / \mathrm{h}$, cell volume of 0.98 cm3 for cylinder cells. The cost of manual black seed planting was 720 L.E./fed. 
Table 2: Operational and production costs of using the developed black seed planter at different values of forward speeds, cells shapes and cells volumes

\begin{tabular}{|c|c|c|c|c|c|c|}
\hline \multirow{3}{*}{ Cells shapes } & \multirow{3}{*}{$\begin{array}{c}\text { Forward } \\
\text { speed, km/h }\end{array}$} & \multirow{3}{*}{$\begin{array}{l}\text { Hourly cost, } \\
\text { L. E./h }\end{array}$} & \multirow{3}{*}{$\begin{array}{l}\text { Operational cost, } \\
\text { L. E./.fed }\end{array}$} & \multirow{2}{*}{\multicolumn{3}{|c|}{$\frac{\text { Production cost, L. E./Mg. }}{\text { Cells volumes, } \mathrm{cm}^{3}}$}} \\
\hline & & & & & & \\
\hline & & & & 0.98 & 1.41 & 1.92 \\
\hline \multirow{4}{*}{ Cylinder cells } & 2 & 54.21 & 74.60 & 104.23 & 100.69 & 97.66 \\
\hline & 3 & 57.35 & 55.81 & 80.56 & 78.07 & 76.75 \\
\hline & 4 & 61.81 & 46.69 & 72.88 & 70.37 & 66.99 \\
\hline & 5 & 67.29 & 41.77 & 68.01 & 65.61 & 62.18 \\
\hline \multirow{4}{*}{ Truncated cone cells } & 2 & 54.21 & 74.60 & 100.75 & 96.52 & 93.77 \\
\hline & 3 & 57.35 & 55.81 & 76.90 & 74.48 & 72.23 \\
\hline & 4 & 61.81 & 46.69 & 69.02 & 66.77 & 63.53 \\
\hline & 5 & 67.29 & 41.77 & 66.25 & 61.98 & 58.92 \\
\hline
\end{tabular}

\section{CONCLUSION}

It was recommended to use the developed black seed planter under the following optimum conditions: Forward speed of 3 $\mathrm{km} / \mathrm{h}$. Cell volume of $1.92 \mathrm{~cm}^{3}$. Using the truncated cone cells.

The obtained results at optimum conditions were: plant emergence of $95.46 \%$, seed yield $0.773 \mathrm{Mg} / \mathrm{fed}$, ground wheel slip of $3.6 \%$, required power of $3.41 \mathrm{~kW}$, specific energy of $3.32 \mathrm{~kW} \mathrm{h/fed,} \mathrm{field} \mathrm{capacity} \mathrm{of} 1.03 \mathrm{fed} / \mathrm{h}$, operational cost of 55.81 L.E/fed, and production cost of 72.23 L.E./Mg.

\section{REFERENCES}

Adekanye,T. A. \& Akande, A. M.(2015). Development and evaluation of a manual multi crop planter for peasant farmers. Elixir Agriculture, 86: 35095-35101.

Adisa, A. F. \& Braide, F. G. (2012). Design and development of template row planter, Transnational Journal of Science and Technology 7:27-33.

Afify, M. K. 2011, Development of a seed drill feeding device to suit planting in hills. Misr J. Ag. Eng., 26(1): 561-579.

Al-Mahasneh, M. A., Ababneh, H. A. \& Rababah, T. (2008). Some engineering and thermal properties of black cumin (Nigella sativa L.) seeds. International Journal of Food Science and Technology, 43, 1047-1052.

Awady, M. N. (1992). Farm machines, Txtbk, Col. Ag., A. Shams U.; 120 P.FAO, 2019. Statistical Year book.

Awady, M.N. (1978). Tractor \& farm machinery. Text Book, Fac. Of Agric., Ain-shams University, 164-167.

Bamgboye, A. \& Mofolasayo, A. (2006). Performance evaluation of a two-row okra planter. Agricultural Engineering International: the CIGR journal. Manuscript PM 06 002. Vol. VIII. July.

Coates, W. (1992). Performance evaluation of a pendulum spreader. Transactions ASAE, 8 (3): 285 - 288.

Darakhshan, S., Tahvilian, R., Colagar, A. H. \& Babolsar, I. (2015). Nigella sativa: a plant with multiple therapeutic implications. International Journal of Pharmacognosy, 2, 190-214

Donnell, H. (1983). Farm power and machinery management, 8th ed. lowa state University, Press Ames, USA. Ames, lowa, USA.

Grewal, R.S. (2014). Development and evaluation of tractor operated planter for onion crop, M. Sc., Department of Farm Machinery and Power Engineering, College of Agricultural Engineering and Technology Punjab Agricultural University: $32-33$.

Ibrahim, M.M., Abd El-Mageed, H. N. \& Abd- Alla, T. H. (2008). Development and evaluation a small machine for soaked rice direct planting. Misr Journal of Agricultural Engineering 25: 655-676.

Kyada, A. R. \& Patel, D. B. (2014). Design and development of manually operated seed planter machine, 5th International and 26th All India Manufacturing Technology, Design and Research Conference (AIMTDR 2014) December 12th-14th, 2014, IIT Guwahati, Assam, India.

MALAR (2007). Economic affair sector, Agricultural statistics crops.

Ministry of Agricultural and land reclamation, Medicinal and Aromatic Plants Research Department, Horticulture Research Institute, Agricultural Research Center (2005). book of cultivate of black seed No.9.

Prajaiah, Inder. M., Adarsh K., Satish D., Ashok K. S. \& Cini V. (2016). Development and evaluation of electronically controlled precision seed-metering device for direct-seeded paddy planter. Indian Journal of Agricultural Sciences 86 (5): $598-604$.

Rajsekhar, S. \& Kuldeep, B. (2011). Pharmacognosy and pharmacology of Nigella sativa- A review. International. Research Journal of Pharmacology 2: 36-9.

Valentin, M. T., 2016, Development of a vertical disc push-type double-row carrot seeder for small-scale farmers, The Clsu International Journal of Science and Technology 2: 26-33.

Yehia, I. (1997). Factors affecting the design of a feeding device for crop seeders, Ph. D. Th., Fac. of Ag. Ain Shams U.: 109116.

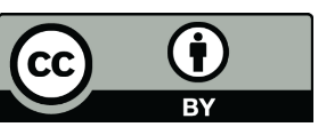

Copyright: (C) 2021 by the authors. Licensee EJAR, EKB, Egypt. EJAR offers immediate open access to its material on the grounds that making research accessible freely to the public facilitates a more global knowledge exchange. Users can read, download, copy, distribute, print or share a link to the complete text of the application under Creative Commons BY-NC-SA 4.0 International License. 


\section{تطوير وتقييم آلة لزراعة حبة البركة

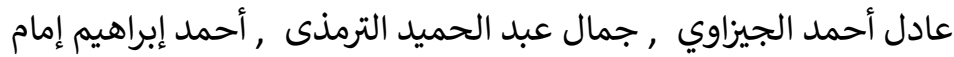

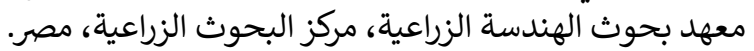 \\ a.emam@arc.sci.eg بريد المؤلف المراسنة الراعلة}

الهدف من هذا البحث هو تطوير وتقييم آلة لزراعة بذور حبة البركة ـ لذلك فقد تم إستبدال جهاز التلقيم ذو الخلايا

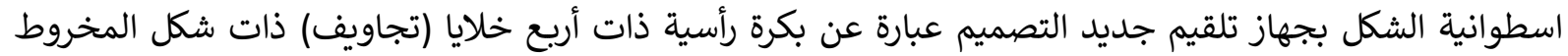

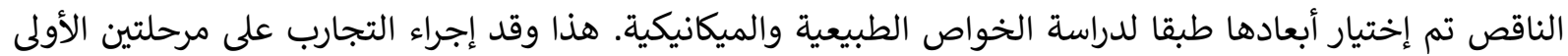

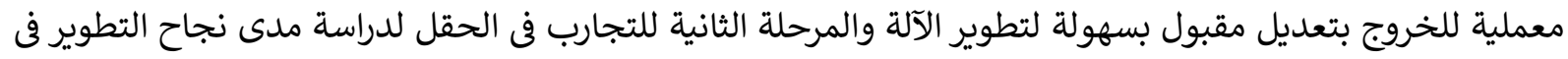
إمكانية زراعة بذور حبة البركة ميكانيكيا:

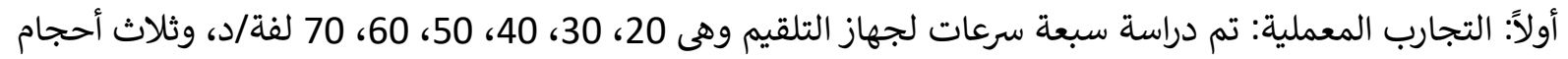

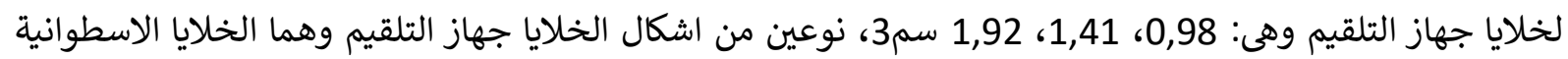
والخلايا ذات شكل المخروط الناقص.

ثانياً: التجارب الحقلية: تم أختبار أريع سرعات أمامية وهى 2، 3، 4، 5 كم/س مع نفس أحجام خلايا جهاز التلقيم السابقة

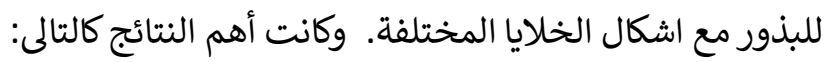

* في الإختبارات المعملية، وجد أن أقصى معدل زراعة للبذور وهو 1,71 كج/فدان و أقل نسبة تلف للبذور 0.32 \% و

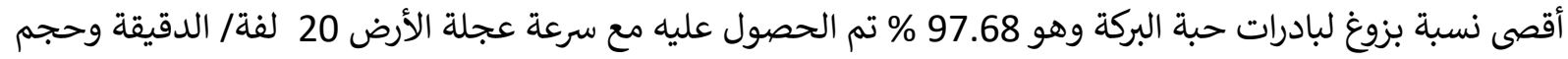

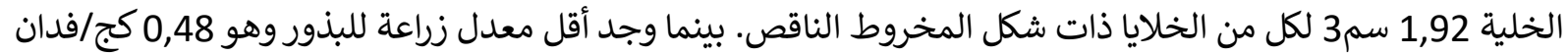

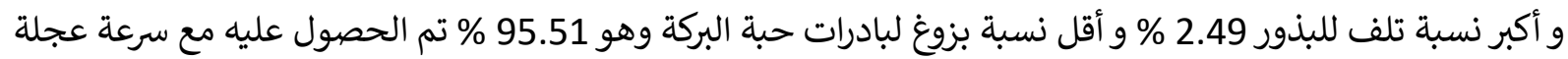
الأرض 70لفة/ الدقيقة 0,98 سم3 لكل من الخلايا الاسطوانية.

* ف الإختبارات الحقلية، وجد أن باستخدام السرعة أمامية 2 كم/ساعة وحجم الخلية 1,92 سم3 مع الخلايا ذات شكل

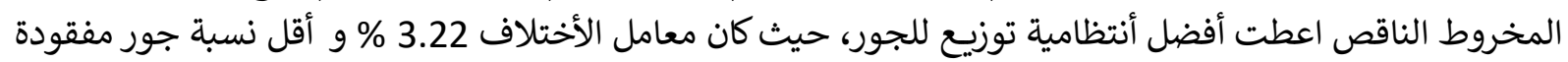

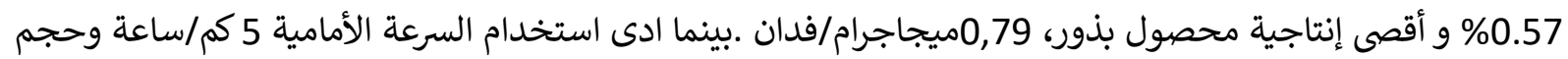

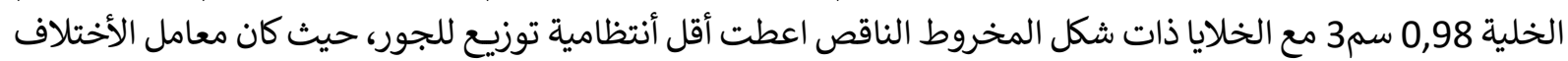
14.44 \% وأكبر نسبة جور مفقودة 4.48\% و أقل إنتاجية محصول بذورو،

وجد أن أقل تكاليف تشغيل 41.77 جنية / فدان و58,92 جنيه / طن تم الحصول المعاعة عليها بإستخدام جهاز آلة زراعة بذور

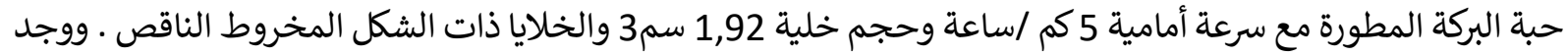
أيضاً أن تكاليف التشغيل للزراعة اليدوية في جور 720 جنيه/فدان. الكلمات المفتاحية: حبة البركة، الحبة السوداء، زارع البذور، وجهاز قياس. 